\title{
INFORMAÇÃO E MUDANÇAS
}

Gabriela Belmont de Farias *

\section{RESENHA}

SOUTO, Leonardo Fernandes (Org.). O profissional da informação em tempo de mudanças. Campinas: Alínea, 2005. 102p.

A globalização, as novas tecnologias e o valor adquirido pela informação na sociedade pós-industrial provocaram o surgimento de novas ocupações profissionais no mercado de trabalho. O valor da informação para o desenvolvimento organizacional e pessoal é reconhecido pela sociedade pós-industrial, mas a mesma desconhece a atuação do bibliotecário como profissional capaz de transformar a informação em serviços e produtos informacionais com fins de dinamizar o processo de desenvolvimento socioeconômico do país.

Diante desse paradoxo, Leonardo Souto bibliotecário da UNICAMP e doutorando na ECA/USP, organizou este livro contendo cinco ensaios de autores distintos. Nele são abordados alguns fragmentos referentes ao trabalho do bibliotecário: a ampliação de seu campo de atuação e sua postura profissional, ambas do ponto de vista do mercado empresarial, do ambiente social e do usuário da informação.

O primeiro ensaio é escrito por Danielle Ferreira, Bibliotecária da UNICAMP e doutoranda da ECA/USP, que propõem uma reflexão sobre a capacitação, perfil e atuação do bibliotecário diante do atual contexto do mercado de trabalho, sob o enfoque das empresas de recursos humanos. A autora analisa quais são os profissionais da informação que as organizações buscam no mercado de trabalho através das empresas de recursos humanos, para gerenciar os fluxos e estoques de informação, de forma a eliminar os excessos de informação nas organizações e, também, se o bibliotecário está sendo absorvido por estas organizações. É levantada a questão da necessidade do auto-conhecimento do bibliotecário sobre suas competências técnicas e pessoais e da ampliação dessas competências, para que esse profissional possa usufruir das oportunidades do mercado informacional que tem por característica, segundo a autora, a interdisciplinaridade.

O organizador do livro aborda no segundo ensaio as oportunidades oferecidas aos bibliotecários por um mercado que se baseia na comunicação e informação, mas levanta as questões culturais, que conforme o próprio autor dificulta a aceitação e reconhecimento dos bibliotecários pela sociedade. Para Souto, há uma necessidade de (re) direcionar a formação do bibliotecário para as atividades gerenciais e de desenvolvimento de serviços e produtos informacionais adotando a concepção de que seu trabalho gira em torno do fluxo da informação e não apenas do documento, além de oferecer disciplinas de conteúdos políticos e sociais. Essas, conforme o autor, contribuem para formar uma consciência da função do bibliotecário na sociedade e para o bibliotecário na construção do senso crítico mais apurado

\footnotetext{
* Mestranda do Programa de Pós-Graduação em Ciência da Informação da UFSC. gabriela_belmont@yahoo.com.br
} 
de sua própria atuação no mercado de trabalho. O domínio das técnicas de acesso às bases de dados e, igualmente, da tecnologia de informação é apontado pelo autor como um desafio a ser superado pelos bibliotecários. A inclusão do bibliotecário no mercado informacional, conforme Souto, depende significativamente da identificação de oportunidades, das qualificações, da atualização curricular e do envolvimento dos bibliotecários com as entidades de classe a fim de fortalecer a profissão perante a sociedade.

Elisabete Neves, bibliotecária do Sistema Integrado de Biblioteca da USP, descreve no terceiro ensaio a atuação do bibliotecário na gestão do conhecimento. Para autora, o bibliotecário por ter uma formação direcionada a integrar, sintetizar, esquematizar e estruturar o conhecimento em modelos de representações sistêmicos tem uma maior oportunidade de atuar no ramo de gestão do conhecimento, pois é uma área que agrega profissionais da informação independente de sua formação acadêmica. $O$ ensaio aborda ainda a falta de incentivo à educação contínua dos bibliotecários, a insegurança do mesmo em ocupar novos espaços no mercado de trabalho e o problema da identidade profissional do bibliotecário que, segundo ela, desconhece as próprias competências, impossibilitando-se de ampliar o seu campo de atuação.

Os três primeiros ensaios refletem sobre as dificuldades que os profissionais bibliotecários têm em identificar as competências técnicas e pessoais, gerando conseqüentemente insegurança em ocupar cargos em um ambiente (organizações) não muito explorados pela profissão. Os autores também apresentam a preocupação em desmistificar a imagem da profissão, evidenciando suas habilidades de modo integrado; pensam que todas as instituições que representam e formam a classe bibliotecária, principalmente as associações, devem se mobilizar com ações estratégicas para que a sociedade visualize e usufrua da potencialidade do fazer bibliotecário.

Complementando a idéia de que o profissional bibliotecário tem, de fato, um papel a ser desempenhado na sociedade, Flávia Barros, bibliotecária da Rede de Ensino SESI, escreve o quarto ensaio. Com ele, leva a uma reflexão sobre a leitura como instrumento de formação intelectual do indivíduo, que não está somente associada ao processo de ensino-aprendizagem, mas aos processos sociais, culturais e educacionais, permitindo uma análise crítica do próprio indivíduo em relação ao contexto no qual está inserido. Para Barros, o bibliotecário é considerado um profissional-cidadão, por suas ações evidenciarem o posicionamento de agente de intervenção e transformação social, tendo como ambiente as bibliotecas escolares e públicas que, conforme a autora, deveriam ser o primeiro ambiente de contato dos indivíduos com a cultura, educação e a informação, porém, são ambientes tratados com descaso pelos poderes públicos e privados.

Finalizando os ensaios, a professora Dr. ${ }^{a}$ Eliana Marquetis descreve um estudo exploratório realizado com usuários de bibliotecas universitárias e institutos de pesquisa, por serem considerados pela própria autora ambientes onde são sentidas as principais mudanças ocorridas com o uso das novas tecnologias. O ensaio reflete sobre como o usuário das bibliotecas universitárias e institutos de pesquisa vêem o bibliotecário, como é o relacionamento usuário e bibliotecários e qual a importância do bibliotecário para o usuário, ou seja, faz refletir sobre o perfil bibliotecário sob a ótica do usuário. 
Os dois últimos ensaios diferenciam-se dos três anteriores, em relação à atuação do bibliotecário no mercado empresarial, por abordarem a responsabilidade social do bibliotecário no contexto político, econômico e cultural e o olhar que o usuário / cliente de informação tem em relação aos profissionais bibliotecários, mantendo a mesma linha de pensamento dos capítulos anteriores.

Os autores chegam ao objetivo proposto que é estimular as reflexões em torno da postura e identidade profissionais do bibliotecário e as múltiplas oportunidades de atuação desse profissional no mercado de trabalho diante das mudanças que ocorrem no mercado global. Porém, a meu ver, há um ponto conflitante que é a variável existente nos ensaios, referente ao termo bibliotecário e à expressão profissional da informação, as quais podem levar o leitor a se perguntar que profissional está sendo descrito.

Pergunto-me: por que não assumirmos o termo bibliotecário, em vez de querer utilizar um termo vago inerente a qualquer formação acadêmica e/ou a profissionais que lidam excessivamente com informação? Pois se analisarmos mais precisamente a identidade profissional de qualquer que seja a profissão, constataremos que as solidificações das profissões estão ligadas à sua evolução histórica e à consolidação do seu fazer ao decorrer das transformações da sociedade. E na mesma proporção em que mudam o comportamento e a estrutura da sociedade, muda também sua maneira de encarar as profissões.

Cada profissão está inserida em uma rede de relacionamento humano na qual ocorrem mudanças na estrutura da consciência, dos sentimentos, dos níveis consciente e inconsciente da personalidade os quais são moldados por vários tipos de dependência que há na teia humana. Há também a influência das instituições sob as quais existem e das funções das quais dependem suas existências sociais. As estruturas das profissões são influenciadas e influenciam a sociedade e é nessa ação de ser influenciado e influenciar que ocorre o processo de consolidação e visibilidade da profissão na sociedade.

A questão está na mudança de comportamento profissional do bibliotecário perante a sociedade e o que nós, enquanto classe organizada, estão fazendo, para que a sociedade visualize o profissional bibliotecário como parte inerente do conjunto dos segmentos sociais para o desenvolvimento socioeconômico do país. 